\title{
LAPORAN NILAI TAMBAH SYARIAH DALAM UPAYA PENINGKATAN AKUNTABILITAS PADA LAPORAN KEUANGAN SYARIAH
}

\author{
Oleh : \\ Arim Nasim \\ (Dosen Program Studi Akuntansi Fakultas Pendidikan Ekonomi \& Bisnis UPI) \\ Maya Meiyaroh \\ (Alumni Program Studi Akuntansi Fakultas Pendidikan Ekonomi \& Bisnis UPI)
}

\begin{abstract}
This study aims to prove that the application of value-added reports of sharia could improve accountability of an Islamic financial report. This research is a qualitative study in which the object is value-added reports sharia itself. The report added value is a proposed Islamic financial statements in accordance with Islamic financial institutions, according to some Islamic scholars such as Iwan Triyuwono, Mulawarman and Ratmono. The study design used is a Research Reflexivity of explaining aspects of the ontology, the human type estimologi and assumptions used in the study. This aspect needs to be disclosed, because the perception of researchers in the form of the system of values and beliefs. Source of data obtained for this study consisted of theoretical issues related to the object that is the verse of the Qur'an and Al-Hadith to corroborate the data presented in this study and added the results of previous studies that support, scientific journals as well as expert opinion in the field of accounting Shariah is certainly familiar with Islamic values with the data collection technique used consists of the analysis of documentary studies (documentary study) and interviews. Based on the obtained results that compared to the income statement. the report can provide value-added Shariah clearer accountability and to improve accountability through the reporting of financial statements worksheets one through value-added reports of sharia.
\end{abstract}

Kenwords: Financial Statement Sharia, Sharia Value Added Statement, Accountability

\section{Latar Belakang}

Kemunculan lembaga keuangan syariah di tengah masyarakat di Indonesia pasca Undang-Undang No.10 Tahun 1998 yang diikuti oleh peningkatan minat masyarakat untuk memanfaatkan jasa perbankan dan lembaga keuangan syariah membawa harapan lahirnya nuansa baru yang lebih baik dalam perekonomian mikro maupun makro. Perkembangan lembaga keuangan syariah khusunya di perbankan syariah mengalami peningkatan setiap tahunnya. Berdasarkan Outlook Perbankan Syariah tahun 2011 yang dikeluarkan oleh Bank Indonesia (dalam www.bi.go.id) sepanjang tahun 2010 perbankan syariah tumbuh dengan volume usaha yang tinggi yaitu sebesar $43,99 \%$ dibandingkan periode yang sama tahun sebelumnya.

Salah satu usaha untuk menyelenggarakan lembaga keuangan yang baik (Good Corporate Governance) sesuai dengan prinsip syariah adalah memenuhi prinsip akuntabilitas. Akuntabilitas dapat dikatakan sebagai suatu pemberian informasi dan pengungkapan (disclosure) atas aktivitas dan kinerja finansial kepada pihak - pihak yang berkepentingan karena akuntabilitas merupakan suatu bentuk perwujudan kewajiban dalam mempertanggungjawabkan keberhasilan atau kegagalan pelaksanaan misi suatu organisasi yang bersangkutan. Dalam surat An-Nisa ayat 85 yang artinya "Sesungguhnya Allah menyuruh kamu menyampaikan amanat kepada yang berhak menerimanya." Ayat ini dapat diintepretasikan dalam konteks akuntansi yaitu Allah SWT memerintahkan agar kita senantiasa dapat menjalankan amanat untuk setiap pihak terkait yaitu bagi pengguna informasi (stakeholders) dan dalam hal ini kaitannya adalah memenuhi hak untuk mendapatkan informasi dari laporan keuangan. Dan dalam kata lain ayat ini mendeskripsikan mengenai prinsip akuntabilitas.

Konsekuensi dari hal tersebut bahwa seluruh proses akuntansi akan dimintai pertanggungjawabannya. Bentuk pertanggungjawaban ini tentu saja harus diwujudkan dalam 
bentuk kinerja laporan keuangan dengan mengungkapkan dan menyajikan setiap materi informasi akuntansi yang dibutuhkan (full disclosure). Perkembangan di bidang akuntansi untuk entitas syariah tak pernah berhenti baik dalam hal penyempurnaan PSAK yang menyesuaikan dengan prinsip syariah maupun dalam praktik penerapannya. Terbukti dengan diterbitkannya Exposure Draft (ED) PSAK 101 revisi 2011 di awal tahun ini. Adanya perubahan format laporan laba rugi supaya meningkatkan daya banding antar entitas syariah. Tujuan laporan keuangan syariah pada dasarnya sama dengan tujuan laporan keuangan secara umum dengan beberapa tambahan. Sekarang permasalahannya adalah apakah dengan komponen laporan keuangan berdasarkan pada PSAK 101 tersebut sudah mencerminkan nilai-nilai akuntansi syariah.

Laporan keuangan konvensional menekankan informasi pada laba atau pertambahan kekayaan pemilik. Kelemahan lain dari laporan laba rugi hanya menggambarkan hak atau kepentingan pemegang saham saja, bukan seluruh yang ikut terlibat dalam kegiatan perusahaan, secara konsep saat ini diakui bahwa pertambahan kekayaan itu adalah usaha semua pihak, bukan hanya pemilik saham atau pengelola sehingga laporan tersebut akan lebih mencerminkan pengungkapan penuh (full disclosure).

Di tahun 1994 dan 2006 Baydoun dan Willet mengembangkan sebuah teori tentang pelaporan keuangan lembaga yang beroperasi dengan prinsip Islami yang dinamakan Islamic Corporate Reportings (ICRs) dan menyarankan salah satunya Laporan nilai tambah sebagai tambahan laporan keuangan. Berbeda dengan laporan laba rugi, laporan nilai tambah syariah mengarah pada kepentingan lebih luas dalam bentuk distribusi pada seluruh stakeholder dan dengan laporan nilai tambah kemampuan lembaga keuangan syariah dalam menghasilkan profitabilitas dihitung dengan juga memperhatikan kontribusi pihak lain seperti karyawan, masyarakat, pemerintah dan lingkungan. Dengan adanya laporan nilai tambah syariah dapat memberikan informasi yang lebih jelas bagi pemakai laporan keuangan. Diadopsinya laporan nilai tambah syariah dalam salah satu laporan keuangan syariah akan sesuai dengan prinsip-prinsip akuntansi syari'ah sebagaimana penelitian kualitatif yang dilakukan oleh Mulawarman tahun 2006.

Rumusan Masa!ah

Berdasarkan uraian latar belakang penelitian di atas, dapat dirumuskan beberapa permasalahan sebagai berihut:

1. Bagaimana suatu laporan keuangan syariah yang sesuai dengan prinsip akuntabilitas?

2. Bagaimana laporan nilai tambah syariah dalam upaya meningkatkan akuntabilitas laporan keuangan syariah?

\section{Kerangka Pemikiran}

Akuntansi merupakan suatu sistem untuk menghasilkan informasi keuangan yang digunakan oleh para pemakaiannya dalam proses pengambilan keputusan bisnis. Pada dasarnya akuntansi bukanlah sesuatu yang statis, tetapi akan selalu berkembang mengiringi perkembangan lingkungan akuntansi. Perkembangan akuntansi syariah saat ini mengalami kemajuan yang pesat menuju karakteristik Islam yang seharusnya dapat menciptakan kebaikan dan kelebihan untuk kehidupan masyarakat sebagaimana yang diungkapkan oleh Triyuwono (2007:29) bahwa "akuntanis syariah lebih menekankan pada pencarian bentuk akuntansi yang tidak saja humanis, beretika. tetapi juga memiliki landasan filosofis religius atau teologikal dari pandangan tersebut." Laporan keuangan yang merupakan hasil akhir dari suatu proses akuntansi diharapkan dapat mendeskripsikan pelaksanaan operasional, tanggung jawab dan kinerja perusahaan. Menurut ED PSAK 101 (Revisi 2011) Laporan Keuangan Syariah yaitu "laporan keuangan yang ditujukan untuk memenuhi kebutuhan bersama sebagian besar pengguna laporan." Namun para pakar syariah seperti Triyuwono, Mulawaran, Harahap, Baydoun dan Willet setuju bahwa laporan keuangan syariah yang saat ini digunakan masih syarat dengan nilai konvensional apalagi untuk laporan laba rugi yang masih memfokuskan informasi untuk pemegang saham, maka mereka mengusulkan suatu laporan yang dapat mencerminkan nilai Islam. Sesuai dengan perkembangann: a para pakar mengkaji suatu laporan yang dinamakan Laporan Nilai Tambah Syariah. Hotman Pohir Tohan (2010:28) menambahkan bahwa "... hal yang penting dalam 
akuntansi Islam, yaitu sebagai suatu bentuk akuntabilitas sosial dan aturan full disclosure . . Rekomendasi khusus bentuk modifikasi tersebut adalah (VAS)."

Andik S. Dwi Saputro (2010:22) menguraikan karakteristik laporan nilai tambah syariah yaitu memenuhi adab dalam bermuamalah, konsep distribusi pendapatan dan memberikan kemudahan. Pemenuhan adab bermuamalah mengandung pengertian bahwa Islam melindungi hak individu dan kolektif dengan menempatkan secara adil sesuai ukuran dan batasannya menurut syariah agar sesama muslim terhindarkan dari memakan harta saudaranya dengan jalan yang bathil. Distribusi pendapatan dalam Islam menurut Sudarsono (2002:235) adalah mengarahkan distribusi pendapatan yang sama rata, letak pemerataan dalam Islam adalah dalam prinsip keadilan atas dasar maslahah. Dan karakteristik kemudahan yaitu kesederhanaan dalam konsep teori dan praktik'akuntansi syariah.

Dari ketiga karakteristik di atas disimpulkan bahwa laporan nilai tambah syariah syarat dengan nilai-nilai Islam dimana kita sebagai hamba Allah SWT berkewajiban untuk mengikuti hukum Islam secara kaffah. Selain itu kebaikan dan keadilan dijunjung tinggi dalam syariah Islam. Konsep saat ini belumlah memberikan keadilan untuk setiap pihak yang terlibat. Pertambahan kekayaan suatu perusahaan itu adalah usaha semua pihak, bukan hanya pemilik saham atau pengeloia sehingga laporan harus lebih mencerminkan full disclosure. Kerangka teori yang telah ada, akuntansi syariah didasarkan pada ketauhidan, tujuan, paradigma, konsep, prinsip harus sesuai dengan nilai-nilai Islam yang diatur dalam al-Qur'an dan al-Hadist. Deferensial dari hal tersebut adalah bahwa tujuan akuntansi harus kembali pada tujuan hakikat dari penciptaan manusia untuk beribadah sebagaimana dalam surat al-Dzariat ayat 56 yang artinya:"Dan tidaklah kami ciptakan jin dan manusia kecuali agar mereka beribadah". Selain itu tujuan tambahan yaitu untuk menjaga lima hal yang substantif dalam kehidupan manusia (maqashid syariah): agama (faith), akal (intellect), jiwa (life), keturunan (lineage), dan harta (property).

Untuk mendapatkan tujuan tersebut para pakar ekonomi syariah merumuskan prinsip dasar yang harus diperhatikan oleh pihak seperti Dewan Dewan Standar Akuntansi Syariah, IAI, dan juga oleh entitas bisnis syariah dalam merumuskan standar akuntansi serta menjalankan praktek yang berlangsung yang dijadikan acuan dan batasan oleh Islam dengan memperharikan seluruh pihak yang terlibat langsung maupun tidak langsung. Prinsip dasar tersebut adalah prinsip kebenaran dan kejujuran, prinsip keadilan dan prinsip akuntabilitas. Penjelasan dari ketiga prinsip ini tentunya sangat berbeda dengan pengertian yang diagungkan oleh akuntansi konvensional.

Salah satu prinsip yang menjadi sering dijadikan sebagai ukuran adalah prinsip akuntabilitas. Pengertian akuntabilitas dalam perspektif Islam menurut Triyuwono (2006:25) adalah "akuntansi syariah tidak saja sebagai bentuk akuntabilitas (accountability) manajemen terhadap pemilik perusahaan (stockholders), tetapi juga sebagai akuntabilitas kepada stakeholders dan Tuhan." Maksudnya adalah segala hal yang dilakukan oleh manusia akan dimintai pertanggungjawaban tidak hanya oleh atasan atau pihak yang berkepentingan tetapi lebih luas adalah bagaimana manusia dapat mempertanggungjawabkannya di depan Allah SWT. Dan pada tataran prakteknya akuntabilitas erat kaitannya dengan transparansi laporan keuangan. Karakteristik akuntabilitas dalam Islam menurut Yaya dan Hameed (dalam Hotman, 2010:41) yaitu pengukuran dan penyajian keuangan. Hal ini penting untuk memenuhi kewajiban sesuai syariah Islam. Konsekuensi dari hal tersebut bahwa seluruh proses akuntansi akan dimintai pertanggungjawaban secara horizontal kepada seluruh pihak yang terlibat tetapi juga secara vertikal kepada Allah SWT.

Akuntabilitas juga merupakan aspek dari penyelenggaraan lembaga keuangan yang baik (Good Corporate Governance). Good Corporate Governance (GCG) yaitu seperangkat aturan yang mengatur hubungan antara para pemegang saham, manajer, kreditur, pemerintah, karyawan, dan pihak-pihak yang berkepentingan lainnya baik internal maupun eksternal lainnya yang berkaitan dengan hak-hak dan kewajiban mereka. Laporan nilai tambah syariah dianggap yang sesuai dengan nilai Islam karena memenuhi prinsip dasar pertanggungjawaban karena suatu tujuan laporan keuangan tidak hanya untuk pengambilan keputusan kearah yang lebih konstruktif tetapi sebagai alat pertanggungjawaban. 


\section{Metode Penelitian}

Penelitian ini menggunakan metode kualitatif. Desain penelitian yang digunakan adalah Research Reflexivity yaitu menjelaskan aspek ontologi, estimologi dan asumsi tipe manusia yang digunakan dalam penelitian. Aspek ini perlu diungkapkan, karena persepsi peneliti di bentuk oleh sistem nilai dan keyakinan. Penelitian ini menjelaskan aspek ontologi yaitu apa yang dimaksud dengan laporan nilai tambah syariah, kemudian aspek epistemologi yaitu bagaimana kebutuhan laporan ini dalam menjawab permasalahan yang sedang terjadi, serta melibatkan asumsi tipe manusia yang diambil dari para pakar ekonomi syariah mengenai laporan nilai tambah syariah.

Sumber data yang diperoleh untuk penelitian ini terdiri dari teori yang berkaitan dengan obyek permasalahan yaitu ayat Al-Qur'an dan Al-Hadist untuk menguatkan data yang disampaikan pada penelitian ini dan ditambah hasil penelitian sebelumnya yang mendukung, jurnal ilmiah serta pendapat pakar di bidang akuntansi syariah yang tentunya paham dengan nilainilai Islam. Sumber data lain yang digunakan adalah melalui wawancara terhadap informan yang pendapatnya dapat diambil untuk menguatkan teori yang sudah ada.

Pemilihan para informan tersebut dilakukan secara sengaja. Informan yang dilibatkan yaitu pakar akuntansi syariah yang memiliki peran penting dalam usulan laporan ini yaitu Iwan Triyuwono. Dipilihnya Iwan Triyuwono menjadi informan karena Iwan Triyuwono merupakan salah satu pakar akuntansi syariah yang mengusulkan diterapkannya laporan nilai tambah syariah. Selain itu, penelitiannya mengenai laporan nilai tambah syariah telah menjadi referensi dalam penelitian ini. Lalu informan yang kedua adalah Arim Nasim, dipilihnya Arim Nasim oleh peneliti karena dapat memberikan pemahaman teoritis yang baik dan pandangan yang idealis mengenai aspek yang diteliti. Selain itu kedekatan dengan peneliti sebagai dosen pembimbing dapat menimbulkan keakraban yang sangat dibutuhkan dalam teknik wawancara mendalam. Selanjutnya untuk informan ketiga yaitu Amir Mahmud. Kepahamannya dalam perbankan syariah menjadi alasan peneliti memilih Amir Mahmud. Keaktifannya menjadi praktisi di majelis pakar DEKOPINWIE dapat membantu pemecaham rumusan masalah penelitian.

\section{Hasil Penelitian dan Pembahasan}

\section{Laporan Keuangan Syariah yarg Sesuai Prinsip Akuntabilitas}

Peneliti memaparkan hasil reduksi dari catatan lapangan hasil, wawancara, dan telaah dokumen yang dilakukan mengenai fokus penelitian dengan aspek yaitu laporan keuangan syariah: Menurut Amir Mahmud, : "Relevansi Laporan Keuangan Syariah masih dalam tataran proses yang akan terus digali oleh pemikir akuntansi. Saat ini laporan keuangan yang dibutuhkan oleh LKS adalah yang memberikan kemudahan kepada pengguna yang merekonsiliasi setiap produknya dengan tepat dan berguna. Laporan keuangan yang dapat meningkatkan akuntabilitas adalah laporan yang transaparan, mudah diakses, mudah dipahami dan tepat waktu."

Sedangkan Iwan Triyuwono memaparkan sebagai berikut : "LKS saat ini menggunakan laporan keuangan syariah yang diadopsi dari laporan keuangan konvensional karena PSAK saat ini yang digunakan pun oleh LKS masih syarat dengan nilai konvensional. Laporan keuangan yang berdasarkan akuntansi syariah harus memberikan kesan yang baik yang memberikan kedamaian (salam) dan kasih sayang yang tidak mencerminkan nilai material dan egoistik sehingga muncui rasa positif serta menghadirkan kesadaran Ketuhanan. Sehingga nilai akuntabilitas terpenting kepada Allah SWT terpenuhi. Laporan keuangan harus menggunakan kata-kata yang bijak dar baik sehingga pesan diterima dengan baik."

Sementara Arim Nasim mengungkapkan sebagai berikut "Laporan keuangan syariah saat ini tidak jauh berbeda dengan laporan keuangan untuk konvensional, walaupun sudah menggunakan SAKS tapi standar akuntansi keuangan syariahnya sendiri masih belum sepenuhnya sesuai dengan syariah. Laporan keuangan syariah harus berbeda diharapkan dapat mencerminkan proses transaksinya yang terjadi apakah halal dan sesuai syariah. Laporan keuangan merupakan alat untuk memberikan pertanggungjawaban kepada pihak terkait dan laporan keuangan tersebut harus memenuhi kebutuhan pengguna."

Peneliti menyimpulkan bahwa dari berbagai pendapat di atas dapat diketahui untuk mendapatkan formulasi laporan keuangan yang sesuai dengan prinsip akuntabilitas maka 
dipengaruhi oleh teori yang melandasinya. Namun harus ditekankan bahwa akuntansi syariah merupakan instrumen akuntabilitas yang digunakan oleh manajemen.

Pemikiran ini mempunyai dua implikasi. Pertama, akuntansi syariah harus dibangun sedemikian rupa berdasarkan nilai-nilai etika syariah sehingga bentuk laporan keuangan syariah dan konsekuensinya informasi akuntansi yang disajikan menjadi lebih adil; tidak berat sebelah, sebagaimana kita temukan pada akuntansi konvensional yang memihak kepada para kapitalis. Kedua, praktik bisnis dan akuntansi yang dilakukan manajemen juga harus berdasarkan pada nilainilai etika syariah

\section{Laporan Nilai Tambah Syariah dalam Upaya Peningkatan Akuntabilitas}

Hasil reduksi dari catatan lapangan, wawancara, dan telaah dokumen yang dilakukan peneliti mengenai fokus penelitian dengan aspek yaitu laporan nilai tambah syariah dalam peningkatan akuntabilitas :

Menurut Iwan Triyuwono : "Laporan nilai tambah syariah merupakan laporan yang diharapkan menjadi laporan keuangan tambahan untuk LKS. Laporan ini memenuhi syarat laporan keuangan syariah yang bersifat "materi" adalah untuk pemberian informasi (akuntansi), dan yang bersifat "spirit" adalah untuk akuntabilitas. Manusia berkewajiban mengelola bumi berdasarkan pada etika syariah, yang konsekuensinya harus dipertanggung-jawabkan kepada Tuhan. Ini merupakan premis utama dari akuntabilitas, yaitu akuntabilitas vertikal. Dalam konteks akuntansi, manusia seolah-olah mengikat kontrak dengan Tuhan. Dalam kontrak tersebut Tuhan sebagai (The Ultiriate Principal) menugaskan manusia untuk menyebarkan rahmat dan kesejahteraan (dalam bentuk ekonomi, sosial, spiritual, politik, dan lain-lainnya) pada manusia yang lain (stakeholders) dan alam (natural environment). Konsekuensinya, manusia memang harus bertanggungjawab atas tugas yang dibebankan ini kepada Tuhan berdasarkan hukum-hukumNya. Namun harus diakui bahwa tugas manusia itu adalah tugas yang membumi. Tugas tersebut menyangkut penciptaan dan penyebaran rahmat kepada manusia yang lain dan lingkungan alam dalam bentuk aktivitas bisnis. Dalam konteks mikro dapat diartikan bahwa sebuah entitas bisnis telah melakukan kontrak sosial (social contract) dengan masyarakat dan alam. Oleh karena itu, hubungan antara seorang agent (manajemen) dengan masyarakat dan alam tidak dapat dijustifikasi dengan entity theory atau principal-agent relationship, tetapi dengan konsep shari'ah enterprise theory seperti yang telah disinggung di atas. Sebagai konsekuensi dari kontrak tersebut, seorang agent harus bertanggungjawab kepada masyarakat (stakeholders) dan alam (universe). Hubungan pertanggungjawaban pada tingkat ini dinamakan akuntabilitas horizontal (horizontal accountability).

Sementara Arim Nasim menyatakan bahwa : "Laporan nilai tambah syariah yang diusulkan oleh banyak pakar merupakan laporan laba rugi konvensional yang menambahkan zakat dan sifat distribusi sebagai ciri dari suatu laporan keuangan syariah. Laporan nilai tambah yang ada sekarang belum dapat mencerminkan proses mengklarifikasi kehalalan transaksi. Jika laporan nilai tambah syariah yang diusulkan oleh para pakar syariah itu dapat menggambarkan proses transaksi maka benarlah laporan itu memberikan nilai tambah yang sesuai syariah. Akuntabilitas suatu perusahaan berbeda dengan akuntabilitas suatu negara, maka mengenai permasalahan negara bukanlah kevaiiban suatu perusahaan.

Dari sudut pandang shari'ah enterprise theory, laporan nilai tambah syariah memiliki nilai keseimbangan yaitu; (1) menyeimbangkan nilai egoistik dengan nilai altruistik dengan (2) nilai materi dengan nilai spiritual. Keseimbangan ini lebih mendekati pada keadilan sebagaimana perintah yang dinyatakan dalam Al Quran dalam surah Asy-Syu'ara ayat 181-184 yang berbunyi:"Sempurnakanlah takaran dan janganlah kamu termasuk orang-orang yang merugikan dan timbanglah dengan timbangan yang lurus. Dan janganlah kamu merugikan manusia pada hakhaknya dan janganlah kamu merajalela di muka bumi dengan membuat kerusakan dan bertakwalah kepada Allah yang telah menciptakan kamu dan umat-umat yang dahulu.

Dari kedua pendapat pakar di samping mengidentifikasikan bahwa keduanya memiliki perbedaan pendapat. Namun perbedaan pendapat tersebut jika disesuaikan dengan teori maka 
saling melengkapi dan memberikan konsep baru mengenai suatu laporan keuangan syariah yang dibutuhkan oleh LKS yang sesuai dengan prinsip syariah.

Penelitian ini memberikan bukti bahwa laporan nilai tambah syariah dapat dijadikan upaya dalam mendapatkan laporan keuangan yang sesuai dengan kebutuhan LKS yaitu tidak hanya memberikan pertangungjawaban saja tetapi memberikan pertanggungjelasan atas aktivitas usahanya yang dituangkan ke dalam suatu laporan keuangan. Itulah esensi dari nilai akuntabilitas dalam perspektif Islam. Hasil penelitian ini mendukung hasil penelitian dari Hotman Tohin Pohan (2010) dan Aji Dedi Mulawarman (2006 dan 2008) yang menunjukan bahwa untuk LKS laporan nilai tambah syariah lebih sesuai. Dan didukung pula hasil penelitian oleh Muhammad Wahyudi tahun 2005 yang menunjukan bahwa kinerja keuangan dihitung berdasarkan rasio ROA dan ROE dengan menggunakan pendekatan nilai tambah menghasilkan rasio yang lebih tinggi dibandingkan dengan pendekatan laba rugi. Perjuangan untuk diterapkannya prinsip syariah harus lebih digali sehingga didapat formulasi untuk laporan keuangan yang tidak memberikan kesan yang sama dengan $k$ onvensional dan dapat menjawab harapan baru untuk akuntansi syariah. Namun tidak ada salahnya format laporan nilai tambah yang sekarang digunakan karena dibandingkan dengan laporan laba rugi, laporan nilai tambah syariah lebih dapat dijadikan sebagai upaya meningkatkan akuntabilitas.

\section{Simpulan}

Berdasarkan hasil penelitian mengenai "Laporan Nilai Tambah Syariah dalam Upaya Peningkatan Akuntabilitas pada Laporan Keuangan Syariah", maka peneliti menarik kesimpulan
sebagai berikut:

1. Laporan keuangan yang sesuai dengan prinsip akuntabilitas merupakan laporan keuangan syariah memenuhi pertanggungjawaban kepada Allah dengan mengikuti aturan Islam dalam bermuamalah dan pemenuhan pertanggungiawaban kepada stakeholders. Laporan keuangan tersebut memberikan nilai lebih yaitu memberi perubahan positif pada penggunanya dalam membuat keputusan dan pengaruh yang baik bagi pengguna namun hal positif tersebut harus diiringi dengan tergambamya suatu proses transaksi yang halal dan thoyib sesuai dengan aturan syariah. serta memberikan pertanggungjawaban yang jelas terhadap stakeholder atas kepemilikan dan pembagian resiko dan keuntungan. Pelaporan tersebut dapat terwujud apabila pelaporan akuntansi dilakukan dengan: benar; cepat; terang, jelas, tegas dan informatif; menyeluruh; ditujukan kepada semua pihak; terperinci dan teliti; tidak terdapat unsur manipulasi; dan dilakukan secara kontinyu. Dan tentunya laporan tersebut telah diaudit oleh auditor yang independen dan amanah.

2. Laporan nilai tambah syariah dapat memberikan pertanggungjawaban yang lebih jelas jika dibandingkan dengan laporan laba rugi artinya dapat dijadikan sebagai upaya meningkatkan akuntabilitas LKS melalui pemenuhan prinsip akuntabilitas terhadap Allah dan stakeholders. Dapat dijadikan jawaban atas permasalahan egoistik dan materialistik pada suatu laporan keuangan karena tidak hanya bersifat materi yang tujuannya adalah untuk pemberian informasi (akuntansi) tetapi juga yang bersifat spirit yang terlihat dari pembagian kesejahteraan pada kelompok dalam lingkungan entitas. Laporan nilai tambah syariah akan lebih bernilai tambah jika laporan ini dapat mencerminkan proses transaksi yang berlangsung.

\section{Saran}

Diharapkan dari hasil penelitian ini peneliti dapat menyumbangkan kontribusinya berupa saran-saran sebagai berikut:

1. Bagi lembaga keuangan syariah, laporan keuangan yang diterbitkan saat ini cenderung memfokuskan pada pihak-pihak tertentu sehingga berpengaruh pada pengambilan keputusan. $\mathrm{Hal}$ ini tentu tidak sesuai dengan prinsip syariah. Diharapkan dengan kondisi seperti itu, LKS lebih memperlihatkan nilai-nilai Islam dalam bermuamalah sehingga masyarakat lebih percava sehingga tingkat akuntabilitas LKS dapat terukur dengan baik

2. Bagi peneliti lebih lanjut yang tertarik untuk meneliti permasalahan yang sama, disarankan untuk mengembangkan rumusan formula laporan nilai tambah syariah yang dibuat oleh para pakar sebelumnya. Adapun penelitian ini dapat dilanjutkan dengan menggunakan metode 
kuantitatif untuk menganalisa kinerja laporan keuangan dan membandingkan dengan laporan keuangan saat ini.

3. Bagi para pakar akuntansi syariah yang berjuang demi terlaksananya prinsip syariah diharapkan tidak pernah berhenti dan terus menghasilkan konsep baru dan semoga penelitian ini dapat menjadi tambahan dalam mencari formula laporan keuangan yang tidak hanya menggambarkan angka-angka namun mmeperlihatkan dan memberikan keyakinan bahwa laporan keuangan yang disajikan benar termasuk transaksi yang terjadi.

\section{Daftar Pustaka}

Andik S. Dwisaputro. (2009). Koreksi Konsep Nilai Tambah Syari'ah: Menimbang Pemikiran Konsep Dasar Teoritis Laporan Keuangan Akuntansi Syariah. Simposium Nasional Akuntansi XII. Juli. Makassar

Ikatan Akuntan Indonesia. (2009). Kerangka Dasar Penyusunan dan Penyajian Laporan Keuangan Syariah. Jakarta: Ikatan Akuntan Indonesia

Ikatan Akuntan Indonesia. (2011). Exposure Draft PSAK 101 Revisi 2011. Jakarta: Ikatan Akuntan Indonesia

Imaniar Prihandini. (2010). Pengaruh Akuntabilitas Ditinjau dari Konsep Good Governance Terhadap Kinerja Dinas Perkebunan Provinsi Jowa Barat. Skripsi. Bandung: Fakultas Ekonomi Universitas Widyatama

Iwan Triyuwono. (2006). Respektif Metodologi dan Teori Akuntansi Syariah. Jakarta: PT Raya Grafindo Persada

Iwan Triyuwono. (2007). Mengangkat "Sing Liyan" untuk Formulasi Nilai Tambah Syariah. Simposium Nasional Akuntansi X. Juli: Makasar

Munawir. (2004). Analisa Laporan Keuangan. Yogjakarta: Liberty Yogjakarta

Pohan, Hotman Tohin. (2010). Penerapan Laporan Nilai Tambah Sebagai Upara Meningkatkan Aspek Keadilan: Sebuah Kajian Teori Akuntansi Islam. [Online]. Tersedia: htip://hotmanpohan.blogspot.com/2010/09 penerapan-laporan-nilai-tambah-sebagai.html. [6 September 2010]

Sudarsono, Heri. (2002). Konsep Ekonomi Islam: Suatu Pengantar. Yogjakarta: Ekonisi 